IZA DP No. 9783

Levelling the Playing Field:

The Effects of Slovenia's 2013 Labour Market Reform

Matija Vodopivec

Suzana Laporšek

Milan Vodopivec

February 2016 


\title{
Levelling the Playing Field: The Effects of Slovenia's 2013 Labour Market Reform
}

\author{
Matija Vodopivec \\ University of Primorska and Bank of Slovenia
}

Suzana Laporšek

University of Primorska

\author{
Milan Vodopivec \\ University of Primorska, \\ International School for Social and Business Studies, Celje and IZA
}

\author{
Discussion Paper No. 9783 \\ February 2016
}

\author{
IZA \\ P.O. Box 7240 \\ 53072 Bonn \\ Germany \\ Phone: +49-228-3894-0 \\ Fax: +49-228-3894-180 \\ E-mail: iza@iza.org
}

\begin{abstract}
Any opinions expressed here are those of the author(s) and not those of IZA. Research published in this series may include views on policy, but the institute itself takes no institutional policy positions. The IZA research network is committed to the IZA Guiding Principles of Research Integrity.

The Institute for the Study of Labor (IZA) in Bonn is a local and virtual international research center and a place of communication between science, politics and business. IZA is an independent nonprofit organization supported by Deutsche Post Foundation. The center is associated with the University of Bonn and offers a stimulating research environment through its international network, workshops and conferences, data service, project support, research visits and doctoral program. IZA engages in (i) original and internationally competitive research in all fields of labor economics, (ii) development of policy concepts, and (iii) dissemination of research results and concepts to the interested public.
\end{abstract}

IZA Discussion Papers often represent preliminary work and are circulated to encourage discussion. Citation of such a paper should account for its provisional character. A revised version may be available directly from the author. 
IZA Discussion Paper No. 9783

February 2016

\section{ABSTRACT \\ Levelling the Playing Field: The Effects of Slovenia's 2013 Labour Market Reform*}

We examine the effects of a 2013 labour market reform in Slovenia which made permanent contracts less restrictive and fixed-term contracts more restrictive. Using matched employeremployee database covering the entirety of Slovenia's labour market participants, we compare the difference in outcomes for workers employed under permanent vs. fixed-term contracts before and after the legislative change. We find that the reform achieved both its stated goals of reducing labour market segmentation and improving access to jobs for vulnerable groups: (i) it increased the probability of accessing permanent jobs via transitions from both fixed-term jobs and unemployment, and (ii) it improved the accessibility of permanent jobs for both young and old workers.

JEL Classification: J62, J63, J68

Keywords: employment protection legislation, labor market dynamics, labor market segmentation

Corresponding author:

Matija Vodopivec

Faculty of Management

University of Primorska

Cankarjeva 5

6101 Koper

Slovenia

E-mail: Matija.Vodopivec@fm-kp.si

\footnotetext{
* The authors are grateful to Peter Orazem for useful comments, and to Nejc Cvörnjek for excellent research assistance.
} 


\section{Background and summary}

In the recent past, the Slovenian labour market was often regarded as rigid and segmented, thus posing a barrier to faster economic growth and hindering the employment of vulnerable groups. Before the adoption of the Employment Relations Act in 2013, Slovenian employment protection legislation (EPL) was one of the most rigid among OECD countries and the EU, especially regarding the hiring and firing of permanent workers. The OECD index of EPL strictness in 2008 was 2.76, placing Slovenia in 20th place among the $25 \mathrm{EU}$ Member States (Laporšek and Dolenc, 2012). As a consequence, the labour market was highly segmented between workers with permanent contracts, with a rich set of benefits, and those on fixed-term contracts, with meagre protections and benefits. Moreover, the weak ability of firms to adjust to labour market changes - as documented, among others, by the World Economic Forum (2016) - was increasingly viewed as a hindrance to the competitiveness of the Slovenian economy.

In Slovenia, the segmentation along the permanent vs. fixed-term divide has become increasingly pronounced and has particularly affected young workers. In 2011-12, the incidence of fixed-term contracts in Slovenia was 17.5 percent, compared with 13.5 for the non-weighted average of OECD countries; Slovenia's share only lagged behind Poland, Portugal and Spain among European OECD countries (OECD, 2014). Similarly, the share of fixed-term contracts among new hires has been among the highest in the EU (European Commission, 2010; OECD, 2014). Young workers have been particularly hurt by this dichotomy. In 2011, the incidence of temporary contracts (fixed-term, casual, and other temporary work contracts) among 15-29 year olds in Slovenia was 49.7 percent, compared to 29.3 percent for European OECD countries - placing Slovenia at the very top of that list (see also European Commission, 2010, for analysis of earlier periods). ${ }^{1}$ Moreover, while in the majority of European countries young workers have better chances of moving from a fixedterm to a permanent contract than older workers, Slovenia is one of few countries where the opposite is true (European Commission, 2010).

The 2013 Employment Relations Act introduced significant changes aimed at reducing segmentation and increasing labour market flexibility. On the segmentation front, the law reduced the difference in costs between employing a worker under a fixed-term and a permanent contract. For fixed-term workers it introduced severance pay, increased the unemployment insurance contribution rate, and restricted the leeway for contract extensions. For permanent workers it reduced the level of severance pay and the advance notice period as well as, above all, significantly simplified procedures for the dismissal of permanent workers. On the flexibility front - beyond reducing firing costs of workers under the permanent contract - the law allowed for more flexible deployment of workers and introduced the option of monetary compensation instead of reinstatement, among others. As the result of these changes, the strictness of EPL, as measured by the OECD EPL index, decreased for both

\footnotetext{
${ }^{1}$ Data on incidence of temporary contracts is computed from: http://appsso.eurostat.ec.europa.eu/nui/show.do.
} 
permanent and temporary contracts, with the former being just below and the latter just above the average for OECD countries (see Section 2 below).

The effects of EPL on labour market outcomes has been a subject of a large body of theoretical and empirical literature, focusing on the impact on the level of employment and unemployment, on job and worker flows, and on the differential effects on various groups of workers. Most studies find insignificant and some negative effects of rigid EPL on the level of employment, and no effect on unemployment (see recent reviews by Boeri, 2011, and Betcherman, 2012). More unambiguous are the results on the effects on labour market dynamics. Recent micro econometric studies indicate that strict regulations negatively affect worker and job flows and thus labour market transitions. For example, Autor et al. (2007) show that the adoption of wrongful-discharge protections by state courts in the United States had a negative effect on job flows and firm entry. Similarly, Kugler $(1999,2004)$ find that reduction in dismissal costs increased accessions as well as separations of workers in Colombia. The negative impact of employment protection on turnover was confirmed also by cross-country studies performed on aggregate data (Gomez-Salvador et al., 2004; Messina and Vallanti, 2007; Boeri and Garibaldi, 2009), as well as by studies using difference-indifferences approaches on OECD countries (see Micco and Pages, 2006; Haltiwanger et al., 2014; Bassanini et al., 2010; Cingano et al., 2010; and OECD, 2010).

Particularly interesting for the present study are results concerning the effects of partial EPL reforms in Southern European countries, which typically reduced the stringency of fixed-term contracts while keeping EPL for permanent contracts unchanged. Bentolila et al. (2008) show that a 1984 Spanish reform liberalizing fixed-term contracts led to a strong substitution of permanent with fixed-term contracts (whose share in aggregate employment reached 35 percent in the early 1990s), an increase in worker turnover rate, and a reduction in the longterm unemployment rate. Because firms used layoffs as a normal practice, the conversion rates into permanent contracts were reduced from 18 percent in 1987 to 5 percent in 1994 . Aguirregabiria and Alonso-Borrego (2014) also find that the reform mildly increased total employment and firm productivity. The findings of Blanchard and Landier (2002) in the case of France are similar. Following the introduction of fixed-term contracts in early 1980s for workers aged 20-24, the proportion of fixed-term contracts significantly increased and conversion rates from temporary to permanent work decreased. The duration of unemployment and probability of becoming unemployed decreased as well, but only in the early period. In Italy, a reform in the early 1990s introduced higher costs for unjust dismissals of permanent workers for businesses below 15 workers. That resulted in more intensive use of temporary contracts and had negligible effect on net employment (Kugler and Pica, 2008). Boeri and Jimeno (2005) also find that stricter EPL reduces dismissals of permanent workers as compared to fixed-term workers.

The objective of this study is to rigorously evaluate whether the 2013 Employment Relations Act levelled the playing field: whether it reduced labour market segmentation between permanent and fixed-term workers, and improved access to jobs of young and old workers. Year-to-year growth rates of employment under permanent contracts have increased under the 
new law, particularly for young workers (15-29 year olds) and first-time jobseekers, and there are signs of increased flows between the state of unemployment and employment (Working group on labour market legislation changes of the Republic of Slovenia, 2014). Of course, comparisons of indicators and aggregate data may be misleading, as they do not account for changes in the macroeconomic environment or for composition effects (for example, characteristics of the unemployment pool may change if there is a one-time wave of bankruptcies). Obtaining more nuanced insights and certainly pinpointing causality underlying studied relationships requires more sophisticated, for example, quasi-experimental methods, such as the ones employed below.

To identify the effects of legislative changes, the study uses a "double difference" approach. The specific nature of the labour market reform - the fact that employment protection for permanent workers became less restrictive and for fixed-term workers more restrictive allows the identification of the effects by comparing differences in labour market outcomes for these two groups before and after the change of law.

The key findings of the paper are as follows. Confronting labour market segmentation, the new law increased the probability of accessing permanent jobs via transitions from both unemployment and fixed-term jobs (including via the conversion of fixed-term to permanent contracts with the same employer). The reform also helped vulnerable groups: the probability of accessing permanent jobs increased disproportionally for both young and old workers.

In what follows, we first describe the goals and relevant features of the 2013 legislative changes. We also discuss how these changes compare to other countries' recent reforms as measured by the OECD EPL index. This discussion sets the background for a description of the main research questions as well as for the methodology, including the double-difference approach, of addressing them. Next, we describe the comprehensive matched employeremployee database that is used for the empirical analysis. We then motivate the empirical analysis by describing the aggregate transitions between labour market states and present the results of individual-level transition regressions. The final section concludes.

\section{Key changes introduced by the 2013 Employment Relations Act}

The new Employment Relations Act (Official Gazette of the Republic of Slovenia, no. 21/2013) came into effect on April 12, 2013 as part of a comprehensive labour market reform aiming at establishing an adequate balance between employment security and flexibility. The new law pursued three main goals: (i) reducing labour market segmentation, (ii) increasing flexibility, and (iii) strengthening the legal protection of workers. To reduce labour market segmentation, the new law reduced costs associated with permanent employment (including simplification of procedures for firing) and increased costs associated with fixed-term employment. The new law also strengthened legal protection in areas where workers in the past were subject to insufficient protection or misuse. 


\section{(a) Reduction of labour market segmentation}

One of the major goals of the new Employment Relations Act was to foster employment under permanent contracts while curbing employment under fixed-term contract, as well as to stimulate the employment of older workers. Important changes introduced by the law include the following:

i. Reduction of the cost difference associated with employment under permanent vs. fixed-term contracts. Associated changes are as follows:

- Employment under permanent contracts was made more attractive, from the point of view of employers, by:

- Shortening advance notice and monetary costs of layoffs. In particular, the maximum advance notification period was shortened, in case of business reasons, from 120 to 60 days. Severance pay in cases of layoffs for business reasons or incapacity was also reduced, and severance pay upon retirement as well as in-kind work benefits were, under certain circumstances, limited. ${ }^{2}$ Moreover, a number of provisions have been delegated to collective agreements (if they exist), including transportation allowances and wage premium associated with work experience.

- Simplification of procedures for termination of employment under permanent contracts. For example, before laying off a worker the employer is no longer liable to offer him/her another suitable job within the firm; the employer can terminate the probationary period before the planned end, and the new law no longer calls for reinstatement and allows that monetary compensation is paid instead.

- Exemption from payment of unemployment insurance contributions for the first two years for permanent contract hires.

- Employment under fixed-term contracts was made more restrictive and less attractive by:

- Limitations on to the use of fixed-term contracts: the maximum duration of fixed-term contract (or a series of uninterrupted fixed-term contracts related to the same work positon) is two years.

○ Introduction of severance pay for fixed-term contracts.

○ The imposition of five-fold higher contribution rate for unemployment insurance in duration of two years for hires under fixed-term contract.

- Limitations on the use of temporary work agency workers employed under fixed-term contracts.

ii. Increasing access to jobs of vulnerable groups. With the goal of increasing employment opportunities for older workers, the new Employment Relations Act introduced two types of changes. First, it raised the age threshold at which workers are granted special

\footnotetext{
${ }^{2}$ The relevant reductions in severance pay are as follows: under the previous law, workers with 5-10 years of tenure were entitled to an average of 1.9 months of severance pay, to be contrasted with 1.5 months under the new law; and workers with 16-20 years of tenure were previously entitled to an average of 6 months of severance pay, to be contrasted with 4.5 months under the new law.
} 
protection against dismissal. Starting with 2017, special protection against dismissal will be given to workers who fulfil the age requirement of 58 years or to workers who otherwise do not meet the age requirement but who qualify for retirement within five years (in the interim period, the age threshold is to be synchronized with the retirement age that also being gradually raised). Second, the dismissal protection is not granted to workers who, at the time of hiring, already past the threshold of protection dismissal (however, protection dismissal is kept by workers who conclude a new contract by forfeiting present employment).

\section{(b) Increase of labour market flexibility}

Several measures aimed at reducing labour market segmentation served to also increase labour market flexibility. These are the measures aimed at making employment protection under permanent contract less strict, as well as measures aimed at reducing special protection of older workers (see above). In addition to these measures, the new Employment Relations Act also increased labour market flexibility by:

- Reducing limits on the use of temporary agency workers, particularly in cases where the workers employed by these agencies under permanent contracts.

- Making the use of labour more flexible within the firm by (i) increasing possibilities for internal redeployment, and (ii) introducing temporary lay-offs, whereby a worker can be laid off for up to six months a year, with the employer being responsible for paying out 80 percent of the wage (and not 100 percent as under the old law).

- During the layoff advance notification period, granting the worker a right to participate one day per week in employment programs organized by public employment offices.

Note, however, that the 2013 Employment Relations Act includes also some provisions that impede labour market flexibility. These provisions, above all, relate to limitations on the use and the increase of costs of fixed-term contracts (see above).

\section{(c) Strengthening the legal protection of workers}

The most important measures of the new Employment Relations Act in this area include:

- Mandatory inclusion in the employment contract of the reason for fixed-term employment.

- Limitation of the number of fixed-term temporary work agency workers deployed at a firm.

- Granting a right to severance pay in the case of unsatisfactory probationary work.

After the introduction of the new Employment Relations Act, the strictness of EPL in Slovenia, as measured by the OECD EPL index, fell considerably. Above all, the EPL index for individual and collective dismissals (permanent contracts) decreased from 2.67 to 2.39 (which is still slightly above the non-weighted average for OECD countries of 2.28), while the EPL index for individual dismissals for permanent contracts dropped to 1.99 , just below the 
OECD average of 2.04 (Table 1). Despite the increase in rigidity associated with fixed-term contracts, the EPL index for temporary contracts also decreased, from 2.50 to 2.13 - a change that came about because the decrease in the restrictions on the use of temporary work agencies outweighed the increase restrictiveness on fixed-term contracts. ${ }^{3}$ Despite the decrease, the EPL index for temporary contracts remains slightly above the non-weighted average for OECD countries of 2.08 .

Table 1: OECD index of the strictness of employment protection legislation in Slovenia, before and after the enactment of 2013 Employment Relations Act

\begin{tabular}{|l|l|l|l|l|}
\hline & $\begin{array}{l}\text { Individual } \\
\text { and } \\
\text { collective } \\
\text { dismissals } \\
\text { (permanent } \\
\text { contracts) }\end{array}$ & $\begin{array}{l}\text { Individual } \\
\text { dismissals } \\
\text { (permanent } \\
\text { contracts) }\end{array}$ & $\begin{array}{l}\text { Collective } \\
\text { dismissals } \\
\text { (additional } \\
\text { restrictions) }\end{array}$ & $\begin{array}{l}\text { Temporary } \\
\text { contracts }\end{array}$ \\
\hline $\begin{array}{l}\text { Slovenia }-2013, \text { old Employment } \\
\text { Relations Act }\end{array}$ & 2.67 & 2.39 & 3.38 & 2.50 \\
\hline $\begin{array}{l}\text { Slovenia - 2013, new Employment } \\
\text { Relations Act }\end{array}$ & 2.39 & 1.99 & 3.38 & 2.13 \\
\hline OECD average - 2013 (unweighted) & 2.28 & 2.04 & 2.90 & 2.08 \\
\hline
\end{tabular}

Source: http://www.oecd.org/els/emp/oecdindicatorsofemploymentprotection.htm (retrieved Dec. 20, 2015).

It is useful to put the nature and intensity of the Slovenia's 2013 reform in further perspective. Using the classifications introduced by Boeri (2011), the introduction of the 2013 Slovenian Employment Relations Act can be labelled as "complete" (rather than "two-tier"), as the share of the population potentially affected by the reform represents more than 50 percent of the potentially eligible population. Moreover, the reform may also be labelled as "incremental" (rather than "discrete"), as the regulatory change lags behind changes in many other countries - see the comparison of the intensity of the changes in the indices of individual dismissals (permanent contracts) and temporary contracts in Slovenian and in other OECD countries in Figure 1.4

\footnotetext{
${ }^{3}$ Note that the OECD Index of strictness of temporary contracts fails to account for two specific features introduced by the 2013 Employment Relations Act, namely for the imposition of (i) the obligation of paying severance pay to fixed-term workers, and (ii) higher contribution rate for unemployment insurance for hires under fixed-term as compared to permanent contracts. In that sense, the reduction of the Temporary contracts index associated with the introduction of the 2013 law presented in Table 1 is overestimated.

${ }^{4}$ In determining whether Slovenian reform was incremental or discrete, we follow Boeri's (2011) classification only heuristically, not computationally.
} 
Figure 1: Intensity of EPL reforms, Slovenia and other OECD countries, 2008-13

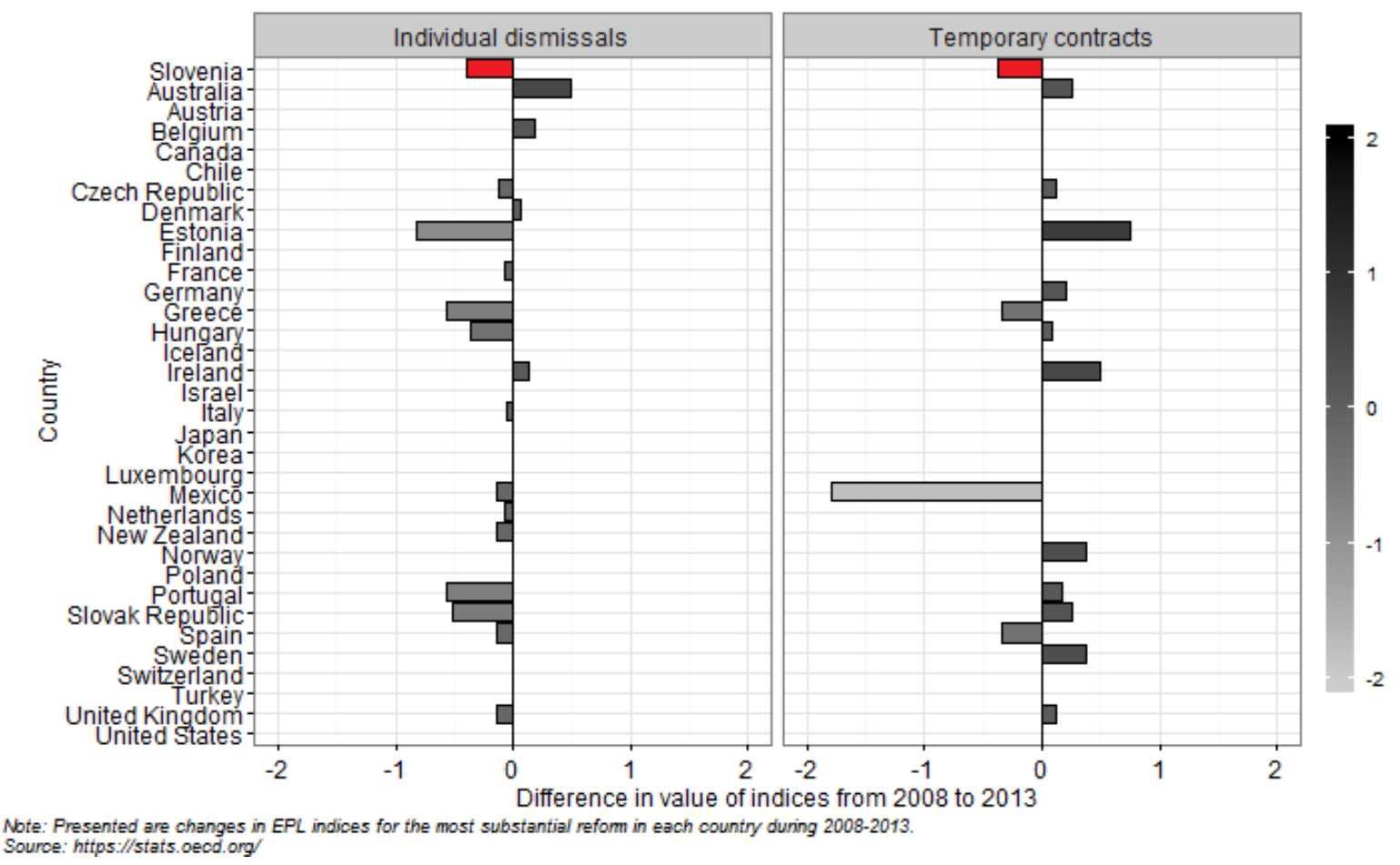

\section{Research questions}

The significant changes introduced by the 2013 Employment Relations Act offer an excellent opportunity for examining the effect of legislative actions on labour market outcomes. This paper focuses on the equity dimension, examining whether, in line with its purported goals, the new law reduced labour market segmentation and increased access to jobs for vulnerable groups. In particular, the paper addresses the following questions:

i. Labour market segmentation: Has under the new law the probability of obtaining a job under the permanent - as opposed to the fixed-term - contract increased? For example, has the probability of obtaining permanent contract increased for workers employed under the fixed-term contract? Similarly, has the probability of obtaining a permanent - as compared to fixed-term contract - increased for the unemployed? Because the new law reduced the cost difference associated with employment under permanent vs. fixed-term contracts, the working hypothesis is "yes" for both cases.

\section{ii. Access to jobs for vulnerable groups:}

- Has the new law increased the probability of accessing a permanent, as opposed a fixed-term, job for young workers? Theoretical predictions (Blanchard, 2000) suggest so, as rigid EPL reduces the availability of jobs for vulnerable groups, especially for young people, because employers prefer to employ workers with previous experience to reduce the possibility of bad choices.

- Similarly, for old workers, particularly for those unemployed - has the new law improved their probability of obtaining a permanent, as opposed a fixed-term, job? Improving the employability of old workers was one of the explicit goals of the 
new law, and the law both raised the age threshold at which workers are granted special protection against dismissal as well as removed the dismissal protection to some groups of old workers (see above).

As a future task, we intend to broaden the scope of research by studying the effects of the 2013 Employment Relations Act on worker and job flows, as well as on productivity, at the firm level.

\section{Methodology and data}

Below we outline the strategy to identify labour market and productivity effects of the legislative changes, and then present the specification of models to be estimated.

\section{(a) Identification strategy}

Identification of the impact of legislative changes takes advantage of the specific nature of the labour market reform that allows the use of quasi-experimental approach. The 2013 labour reform made employment under permanent contracts less restrictive, and under fixed-term contracts more restrictive, which allows the use of difference-in-differences methodology to identify the reform effects (comparing the difference in outcomes for workers employed under permanent vs. fixed-term contracts, before and after the legislative change).

\section{(b) Estimation model of worker transitions}

To analyse the impact of the changed legislation on transitions between various labour market states, we employ a multinomial logistic regression framework. Under this framework, individuals can transition into multiple, competing states - in our case, into permanent or fixed-term employment contracts (at either an existing or another employer, if applicable), unemployment (with or without unemployment benefits), or inactivity. Each of these $J$ competing states are associated with a specific monthly transition probability

$\operatorname{Pr}\left(y_{t+1}=m \mid \boldsymbol{X}_{\boldsymbol{t}}, y_{t}=b\right)=\frac{\exp \left(\boldsymbol{X}_{\boldsymbol{t}} \beta_{m \mid b}\right)}{\sum_{j=1}^{J} \exp \left(\boldsymbol{X}_{\boldsymbol{t}} \beta_{j \mid b}\right)}$, with $m=1, \ldots, J$

where $m$ denotes one of the $J$ labour market states, $b$ is the base category, and $\boldsymbol{X}$ is a set of control variables. For example, taking fixed-term employment (Efixed) as the base category, the probability of receiving a permanent contract at the same employer (Eperm) can be expressed as

$$
\operatorname{Pr}\left(y_{t+1}=E p e r m \mid X_{t}, y_{t}=E \text { fixed }\right)=\frac{\exp \left(X_{t} \beta_{\text {Eperm } \mid b=E \text { fixed }}\right)}{1+\sum_{j=2}^{J} \exp \left(\boldsymbol{X}_{\boldsymbol{t}} \beta_{j \mid b=E \text { fixed }}\right)}
$$


The results we present are expressed as the ratio of the predicted probabilities of a given outcome compared to the baseline outcome; e.g. in the case above, the relative probability of a conversion from a fixed-term contract to a permanent contract is:

$$
\frac{\operatorname{Pr}\left(y_{t+1}=\text { Eperm } \mid \boldsymbol{X}_{\boldsymbol{t}}, y_{t}=\text { Efixed }\right)}{\operatorname{Pr}\left(y_{t+1}=\text { Efixed } \mid \boldsymbol{X}_{\boldsymbol{t}}, y_{t}=\text { Efixed }\right)}=\exp \left(\boldsymbol{X}_{\boldsymbol{t}} \beta_{\text {Eperm } \mid \text { b=Efixed }}\right)
$$

The example presented in (3) can identify the causal effect of the increased rigidity in fixedterm contracts and decreased rigidity on permanent contracts via double differences: (i) by comparing the two, differentially-affected labour segments, and (ii) by exploiting the timeseries variation. To account for the latter, the set of explanatory variables $\boldsymbol{X}$ contains an indicator variable for the time period after which the reforms were enacted. Because the reforms went into effect on April 12 $2^{\text {th }}, 2013$, we exclude the month of April from the analysis by including an indicator variable for that month. Furthermore, when labour market state $y_{t}$ pertains to unemployment, we include a dummy variable controlling for receipt of unemployment benefits. In addition, the explanatory variables $\boldsymbol{X}$ contain variables for demographic characteristics (gender, age, education) and monthly control variables to account for seasonality in worker separations and accessions.

\section{(c) Data description}

The study takes advantage of an exceptionally rich database, created by the merger of administrative data covering the entire Slovenian workforce. The database contains information on the history of employment, unemployment and wages for the entire work career for each individual for the 1991-2014 period. Each employment spell is linked with the financial and other information of the employer, with all firms in Slovenia being included (the so-called matched employer-employee database). The following data sets are included in the combined database:

(a) Work history data set. It contains the information on the starting and ending date of an employment spell, the type of appointment, occupation, employer identification code, and personal characteristics (gender, age, and education). Through the employer identification code, each employment spell is linked to accounting data on the current employer.

(b) Data set on registered unemployed. It contains starting and ending date, destination of exit, as well as information on the receipt of unemployment insurance benefits. Some additional personal and family characteristics, pertaining to each spell, are also included.

(c) Workers' earnings data set. It contains information on earnings associated with each post-1991 employment spell of an individual (amount of earnings, number of hours worked, starting and ending date of earnings period).

(d) Accounting data on enterprises. Data consist of the yearly profit and loss statements, as well as balance sheets, for all incorporated businesses in Slovenia.

(e) Slovenian Business Registry data set includes information on the four-digit industry, the year the firm started operating, and the firm's type and ownership 
structure (private and state ownership, ownership by domestic and foreign owners, and whether a firm is a publicly traded stock company or a limited liability company).

The resulting database that is the basis for this analysis contains over 18 million observations at the level of monthly individual states (Table A1). These span the period from April 2012 to May 2014. The large majority of these observations refer to permanent employment, mirroring the fact that permanent employment comprises the largest share of stock of labour market participants. Men tend to be disproportionally represented among the unemployed and in fixed-term contracts relative to their share in permanent employment; the lesser-educated tend to be disproportionally unemployed, while the highest-educated tend to be disproportionally employed on permanent contracts. Interestingly, the youngest demographic group maintains equal shares of employment among both permanent and fixed-term contracts - this peculiarity can be explained by a unique feature in the Slovenian labour market, the institution of so-called student work. This extremely flexible form of employment represents a large share of employment among the youngest population, but is unfortunately not captured in our data.

\section{Results of empirical analysis}

Below we first contrast pre- and post-reform dynamics in aggregate labour market outcomes, and then present the results of individual-level transition regressions.

\section{(a) Dynamics of labour market transitions}

Aggregate trends on worker accessions following the implementation of the new law suggest that it was indeed successful in its goal of reducing labour market segmentation. For example, following the introduction of the new law in April 2013, the number of worker accessions on permanent contracts increased, while worker accessions on fixed-term contracts decreased (Figure 2). While fixed-term contracts still represent the large majority of accessions, their relative share decreased from 77 percent in the year prior to the legislative change to 73 percent in the year following the legislative change. Moreover, the increases in new permanent contracts were particularly pronounced among younger workers, those aged between 16-29 years. 
Figure 2: Worker accessions by contract type, one-year periods prior to and after legislative change

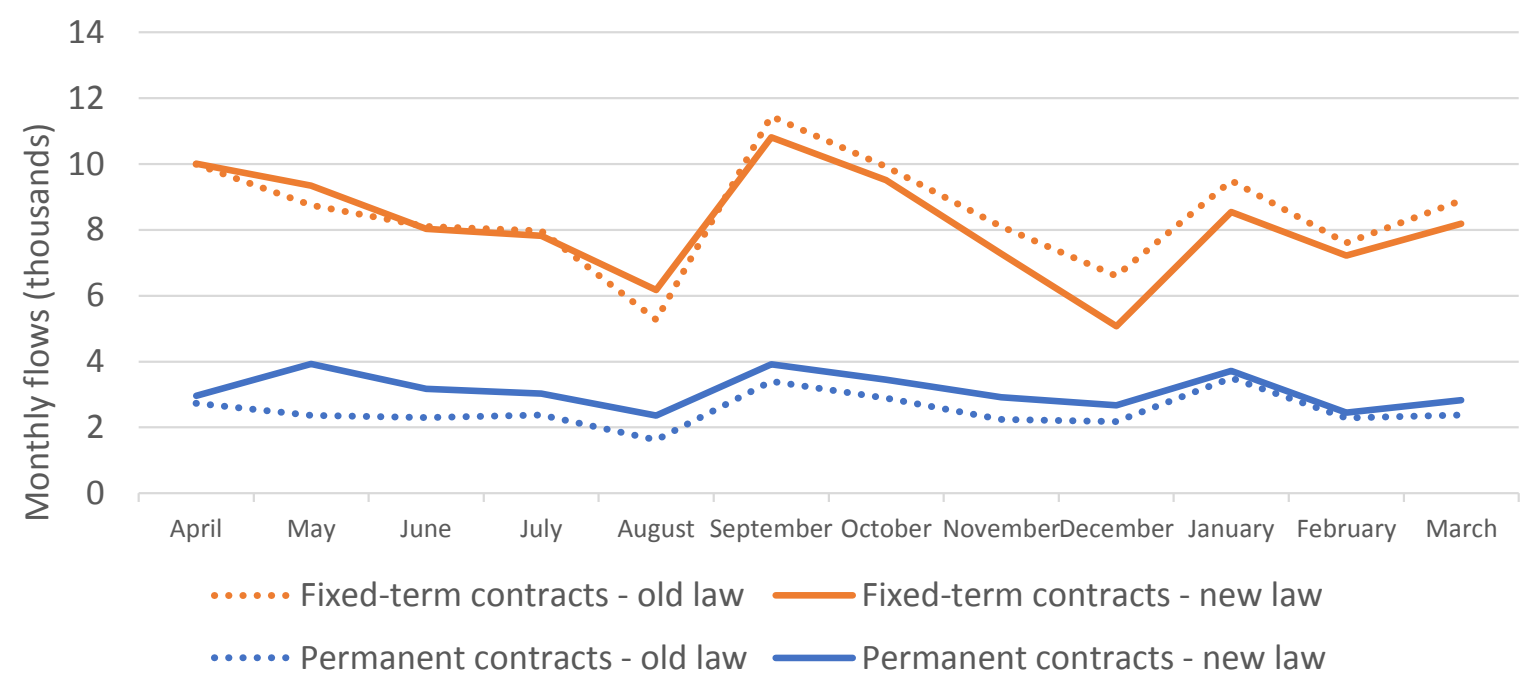

Note: Period covered under old law refers to April 2012 to March 2013; period covered under new law refers to April 2013 to March 2014.

Source: Statistical Office of the Republic of Slovenia.

Which segment of the labour market accounted for the increase in permanent-contract accessions? Detailed statistics on the monthly probabilities of transitioning from one labour market state to another (Table A2) show that the increase in accessions on permanent contracts is largely attributable to an increased accessions from fixed-term contracts at other employers and accessions from other forms of employment (mainly from self-employment). Prior to the legislative change, 1.9 percent of monthly transitions from fixed-term employment resulted in permanent contracts at the same employer; in contrast, after the legislative change the monthly transition rate increased to 2.4 percent. A large share of the increase in accessions to permanent contracts also came from those employed via other contract types: in the year following the introduction of the new law, accessions into permanent contracts increased by 9.8 percent, of which 4 percentage points are attributable to increased inflows from other types of contracts. Accessions from fixed-term contracts had a similar contribution to the increase, 3.8 percent.

The transition matrix also highlights a more stagnant nature of the Slovenian labour market compared to other EU countries. Bachmann et al (2015), for example, report annual persistency rates in permanent employment of 89.7 percent for a panel of 24 EU countries; the comparable figure calculated from the Slovenian administrative data is 91.2 percent. $^{5}$ Furthermore, exit rates from unemployment to permanent employment averaged 8.8 percent in Slovenia, compared to 9.1 percent in EU countries.

\footnotetext{
${ }^{5}$ Note that the figures are not directly comparable due to differences in data sources and definitions - Bachmann et al (2015) use EU-SILC survey data and directly examine annual persistency rates, while the figures for Slovenia are calculated from monthly transition rates. Also note that figures refer to comparable time periods.
} 


\section{(b) Results of the estimation of multinomial logit models of labour market transitions}

Below we present the results of multinomial regressions of transitions across various labour market states. We present three types of transitions:

- Transition from fixed-term employment

- Transition from permanent employment

- Transition from unemployment

In the estimated models, the following destinations are considered: fixed-term employment, permanent employment, unemployment with the receipt of benefits, unemployment without the receipt of benefits, inactivity, and other (for example, self-employment). In transition models with employment as the origin, a further distinction is made between employment with a new as opposed with the current employer (in transition models from permanent employment, transition to fixed-term employment with the same employer is ignored, as such transitions are very rare).

The estimated models follow the multinomial logit specification from equation (2) above, with the key parameter of interest being the parameter showing the difference-in-differences effect on the selected outcome (see the methodology section above). As control variables, we include gender, age, and education, all expressed as categorical variables. Because outcomes by age categories, are of particular interest, models are estimated separately by age categories. Relative risk ratios are presented.

\section{i. Transition from fixed-term employment}

The new law increased the relative probability of transition from fixed-term to permanent contract. We distinguish between two types of these transitions, one in which a fixed-term contract is converted into a permanent contract at the same employer, and another where an individual gets a permanent position at another employer. First, as shown in Table A3, under the new law the probability of transitioning to a new permanent job with another employer increased by 18.9 percent in comparison to the pre-reform period, and the probability of transitioning to a new fixed-term job with another employer decreased by 9.9 percent (Table A3, coefficients under "New Law"). The relative probability of transitioning to a permanent contract (as compared to transitioning to a fixed-term contract) thus increased by 32 percent. Second, under the new law the probability of the conversion of a fixed-term to a permanent contract by the same employer increased by 28.2 percent. $^{6}$ Note that this applies for the chosen baseline characteristics (men, younger than 30 years, with elementary education). Under the new law, the probability of transitions to other destinations (inactivity, covered and uncovered unemployment, and other) also changed, but these changes cannot be attributed to

\footnotetext{
${ }^{6}$ Note that in Table A3, the coefficient for "Permanent employment - same employer" under "New law" already reflects double difference. In contrast, coefficients under "New law" for "Fixed-term employment - new employer" and "Permanent employment - new employer" reflect only the "before-after" difference and a double difference is obtained by their division (as coefficients are relative risk ratios).
} 
the change of the law alone as, in all likelihood, they reflect also changes in other circumstances.

While not directly tied to the legislative changes, it is interesting to note that the employment outcomes generally tend to be superior for men and more highly-educated individuals (Table A3). Although they have higher probabilities of transitioning to self-employment, women on fixed-term contracts tend to have lower probabilities for continued regular employment in any form, permanent or fixed-term, and at either their current or another employer. They also have a higher probability of exiting to unemployment (although intriguingly, not inactivity). More highly educated individuals, on the other hand, have a higher probability of transitioning into permanent contracts (either at their current or at a new employer) and lower probability of transitioning into unemployment; similar to women, they have a higher probability of becoming self-employed and a lower probability of becoming inactive.

Relative probabilities of transitions from fixed-term employment do not vary strongly across age groups. As shown in Table A4, under the new law the probability of transition to a new permanent job with another employer increased for all age groups, and the probability of transition to a new fixed-term job with another employer decreased, also for all age groups, with no group showing particular advantage over the others. Interestingly, the conversion of a fixed-term to a permanent contract by the same employer recorded the highest probability among 40 to 49 year-olds.

\section{ii. Transition from permanent employment}

The new law increased the relative probability of transition from a permanent to another permanent contract with a new employer for both young and old workers. In the aggregate, under the new law the probability of transition from a permanent to another permanent contract with a new employer decreased by 8.9 percent, nearly precisely by as much as did the probability of transition to a fixed-term contract with a new employer, leaving the relative probability unchanged (Table A5). But both young and old workers fared better: for young (16-29 year olds) relative probability of accessing another permanent contract with a new employer increased by 7.6 percent, and for old (those older than 55 years) by 32 percent (Table A6). The explanation for the latter effect can be found in the new law: with the intention of increasing access to jobs by older workers, dismissal protection stopped to be granted to job movers above 55 years old.

Other results show that probabilities of transition from a permanent to another permanent or to fixed-term contract with a new employer differ across various groups (Table A5). Women are less like to change their employers than man, particularly when exiting to fixed-term employment. Interestingly, more educated are less likely to transition from a permanent to a fixed-term contract or to another permanent contract with a new employer, except those with tertiary education when making transition from a permanent to another permanent job. 


\section{iii. Transition from unemployment}

Although the new law coincided with an increase in the outflows from unemployment to both fixed-term and permanent employment, the increase in outflows to permanent employment was significantly greater. ${ }^{7}$ Transitions into permanent contracts increased by 12.1 percent, whereas transitions into fixed-term contracts increased by only 2.7 percent (a difference that is statistically significant). Interestingly, transitions into self-employment decreased, a finding that is attributable to the fact that subsidies for self-employment were offered to the unemployed to a greater extent in the year prior to the change in legislation.

Transitions from unemployment document that the new law improved accessibility of permanent jobs for both young and old workers. While for younger workers, the exit rate increased to both fixed-term and permanent employment, by 15.3 percent and 29.4 percent, the increase to permanent employment was statistically significantly larger (and amounted to 12.2 percent, taking the ratio of the two coefficients) - see Table A8. For older workers, the exit rate to fixed-term employment decreased by almost 30 percent while the exit rate to permanent employment increased, although the latter was not statistically significant relative to the baseline of remaining unemployed. Relative to exiting to fixed-term employment, however, the change was statistically significant and large in magnitude, amounting to 62 percent. For the other age groups, the relative probabilities to exit unemployment into either fixed-term or permanent employment were not statistically significantly different from each other.

The finding that transitions into permanent employment increased significantly for the oldest group of workers can be explained by legislative changes which selectively reduced the firing costs for precisely these workers while leaving them unchanged for younger ones. Prior to the implementation of the new law, workers aged 55 and over were categorically guaranteed job security; layoffs were possible only in cases of gross negligence. As explained above, according to the new law, this special protection no longer applies for new hires who are above the age threshold at the time of the hire. ${ }^{8}$ As such, employers have a much stronger incentive to hire older workers who are above the age threshold, while continued disincentives are in place for hiring workers just below the age threshold (who will soon be subject to the increased job security).

The exit rates from unemployment into employment across demographic characteristics are consistent with those found in other studies (e.g. Bachmann et al, 2015). Women are found to have lower rates of exiting unemployment to either permanent or fixed-term employment than men, but not to self-employment. Exit rates into regular employment decrease with age, while exit rates into self-employment increase with age (although in general, exit rates into self-

\footnotetext{
${ }^{7}$ Note that the statistics reported here refer to exits from both covered and uncovered unemployment.

${ }^{8}$ The precise stipulations for what constitutes an older workers are slightly more complicated: they were lower for women prior to April 2013, are gradually increasing over time, and are also linked to the age at which individuals may retire. These factors are taken into account in the empirical analysis but are not referred to in the text for simplicity of exposition.
} 
employment are much lower than into regular employment). Finally, higher levels of education are associated with much higher exit rates into employment in general, and permanent or self-employment in particular.

\section{Conclusion}

The results of the paper indicate that the 2013 Employment Relations Act achieved its stated goals of reducing labour market segmentation as well as improving access to jobs of vulnerable groups. On the labour market segmentation front, the new law increased the probability of accessing permanent jobs: (i) the probability of conversion from a fixed-term to a permanent contract with the same employer increased, (ii) workers employed under fixedterm contracts increased the probability of obtaining a permanent rather than fixed-term job with another employer, and (iii) unemployed workers increased the probability of obtaining a permanent rather than fixed-term job. On the vulnerable groups front, the new law improved accessibility of permanent jobs both for young and old workers. Young workers can better access permanent jobs via transitions from unemployment and from permanent contract; old workers can better access permanent jobs via transitions from unemployment as well as from another permanent job.

How can the paper's results be interpreted? Slovenia's 2013 new Employment Relations Act reduced job security for permanent workers and increased the costs associated with fixed-term employment. This stands in contrast with reforms in countries that traditionally have had strict EPL, especially in Southern Europe, where for reasons of political expediency easing of protection has been achieved by expanding the scope for fixed-term contracts rather than reducing job security for permanent workers. Our results show that Slovenia's strategy has paid off. Rather than increasing the segmentation - dualism - of labour markets, the result produced by countries that expanded the scope for fixed-term contracts (see above on the effects of partial labour market reforms), Slovenia decreased labour market segmentation. And by increasing flexibility, the 2013 reform also improved job accessibility for vulnerable groups - for both young and old workers. The "completeness of the reform" - the fact that the reform affected both fixed-term and permanent contracts - may well have contributed to these outcomes.

The above results need to be qualified in several ways. First, the results are of partial equilibrium nature, thus ignoring general equilibrium effects of the new law. Such effects can be substantial and involve, among others, interactions between temporary and permanent contracts (for a theoretical modelling of "two-tier reforms," see Boeri 2011). Second, the presented results are preliminary, as applying the analysis to longer time series may improve the reliability of the results and, by investigating longer-term effects, increase their richness. Third, the results focus on a limited set of outcomes, so extending the analysis to other outcomes that may be affected by the new law - including effects on wages and productivity would help producing a more balanced view of the impact of the law.

In our future research we intend to complement the outcomes studied above by examining the impact of the new law on worker and job flows, as well as on productivity at the firm level. 
The research of separations and accessions of permanent and fixed-term workers, both by type of workers and in aggregate, will shed light on the general equilibrium results and thus provide a more complete picture about the effects of the 2013 Law than partial equilibrium results presented above. We also plan to study the impact on the new law on firm-level productivity, as these results lead to broader questions regarding effects of the reforms. For example, has the 2013 Employment Relations Act increased the competiveness of the Slovenian economy? In particular, has the new law increased firm-level productivity, as lower dismissal costs and less strict dismissal procedures for permanent workers may have enabled firms to react quicker to changes in technology and product demand? On the other hand, has more restrictive use of fixed-term contracts reduced productivity of firms, as may also be conjectured? Moreover, has a lesser effective burden of EPL reduced a firm's incentive to invest in firm-specific human capital, reducing the scope for productivity gains in the future? Answering such questions will lead to a deeper understanding of the long-term consequences of the reforms. 


\section{References}

Aguirregabiria, Victor, and Cesar Alonso-Borrego (2014). "Labor Contracts and Flexibility: Evidence from a Labor Market Reform in Spain.” Economic Inquiry 52 (2): 930-57.

Autor, David H., William R. Kerr, and Adriana D. Kugler (2007). "Does Employment Protection Reduce Productivity? Evidence from US States.” The Economic Journal 117 (521): F189-F217.

Bachmann, Ronald, Peggy Bechara, Anica Kramer, and Sylvi Rzepka (2015). Labour market dynamics and worker heterogeneity during the Great Recession-Evidence from Europe. IZA Journal of European Labor Studies, 4(1), 1-29.

Bassanini, Andrea, Andrea Garnero, Pascal Marianna, and Sébastien Martin (2010. Institutional Determinants of Worker Flows: A Cross-Country/Cross-Industry Approach. OECD Social, Employment and Migration Working Paper 107. OECD Publishing. http://econpapers.repec.org/paper/oecelsaab/107-en.htm.

Bentolila, Samuel, Juan J. Dolado, and Juan F. Jimeno (2008). “Two-Tier Employment Protection Reforms: The Spanish Experience." CESifo DICE Report 6 (4): 49-56.

Betcherman, Gordon (2012). "Labor Market Institutions: A Review of the Literature." The World Bank, Policy Research Working Paper \#6276.

Blanchard, Olivier J., and Justin Wolfers, (2000). "The Role of Shocks and Institutions in the Rise of European Unemployment: The Aggregate Evidence." The Economic Journal, 110(462), 1-33.

Blanchard, Olivier J., and Augustin Landier (2001). The Perverse Effects of Partial Labor Market Reform: Fixed Duration Contracts in France. SSRN Scholarly Paper ID 262668. Rochester, NY: Social Science Research Network.

Boeri, Tito (2011). Institutional Reforms and Dualism in European Labour Markets. Handbook of Labour Economics, Vol. 4(B), pp.1173-1236.

Boeri, Tito, and Juan F. Jimeno (2005). "The Effects of Employment Protection: Learning from Variable Enforcement.” European Economic Review 49 (8): 2057-77.

Boeri, Tito, and Pietro Garibaldi (2009). "Beyond Eurosclerosis.” Economic Policy, 24(59), 409-461.

Cingano, Federico, Marco Leonardi, Julián Messina, and Giovanni Pica (2010). "The Effects of Employment Protection Legislation and Financial Market Imperfections on Investment: Evidence from a Firm-Level Panel of EU Countries." Economic Policy 25 (61): 117-63. doi:10.1111/j.1468-0327.2009.00235.x.

Haltiwanger, John, Stefano Scarpetta, and Helena Schweiger (2014). "Cross Country Differences in Job Reallocation: The Role of Industry, Firm Size and Regulations." Labour Economics 26 (January): 11-25. 
Kugler, Adriana D. (1999). The Impact of Firing Costs on Turnover and Unemployment: Evidence from the Colombian Labour Market Reform. Economics Working Paper 388. Department of Economics and Business, Universitat Pompeu Fabra.

Kugler, Adriana D., and Gilles Saint-Paul (2004). "How Do Firing Costs Affect Worker Flows in a World with Adverse Selection?" Journal of Labor Economics 22 (3): 553-84.

Kugler, Adriana, and Giovanni Pica (2008). "Effects of Employment Protection on Worker and Job Flows: Evidence from the 1990 Italian Reform." Labour Economics 15 (1): 7895.

Laporšek, Suzana, and Primož Dolenc (2012). "Do Flexicurity Policies Affect Labour Market Outcomes? An Analysis of EU Countries.” Revija za socijalnu politiku, 19(2), 107-129.

Messina, Julian, and Giovanna Vallanti (2007). "Job Flow Dynamics and Firing Restrictions: Evidence from Europe." The Economic Journal, 117(521), F279-F301.

Micco, Alejandro, and Carmen Pagés (2006). The Economic Effects of Employment Protection: Evidence from International Industry-Level Data. IZA Discussion Paper 2433. Institute for the Study of Labor (IZA).

OECD (2010). OECD Employment Outlook 2010: Moving Beyond the Jobs Crisis. Paris: Organisation for Economic Co-operation and Development.

OECD (2014). OECD Employment Outlook 2014. Paris: Organisation for Economic Cooperation and Development.

European Commission (2010). Employment in Europe 2010. Bruxelles: European Commission: Directorate-General for Employment, Social Affairs and Equal Opportunities, Employment Analysis Unit.

Official Gazette of the Republic of Slovenia (2013), No. 21/2013. "Employment Relations Act."

Vodopivec, Milan (2012). Young People in the Labour Market. Slovenia in the EU Perspective. : Paper presented at the IMAD Conference, Ljubljana, June 19, 2012.

Working group on labour market legislation changes of the Republic of Slovenia (2014). Poročilo delovne skupine za spremljanje učinkov sprememb v regulaciji trga dela v letu 2013. Kajzer, Alenka, Peter Pogačar, Polonca Končar, Milan Vodopivec. Available at http://www.mddsz.gov.si/fileadmin/mddsz.gov.si/pageuploads/dokumenti_pdf/dpd/Anal iza_trg_dela_SL.pdf (in Slovene).

World Economic Forum (2016). The Global Competitiveness Report 2015-2016, http://reports.weforum.org/global-competitiveness-report-2015-2016/, accessed January $31,2016$. 
Table A1: Summary statistics of key variables (mean values of binary variables)

\begin{tabular}{|c|c|c|c|c|}
\hline \multirow[b]{2}{*}{ Variable } & \multicolumn{3}{|c|}{ Labour market state } & \multirow[b]{2}{*}{ Entire sample } \\
\hline & $\begin{array}{c}\text { Permanent } \\
\text { employment }\end{array}$ & $\begin{array}{l}\text { Fixed-term } \\
\text { employment }\end{array}$ & Unemployed & \\
\hline \multicolumn{5}{|l|}{ Gender } \\
\hline Men & 0.52 & 0.59 & 0.54 & 0.55 \\
\hline Women & 0.48 & 0.41 & 0.46 & 0.45 \\
\hline \multicolumn{5}{|l|}{ Age } \\
\hline Age under 30 & 0.08 & 0.08 & 0.07 & 0.08 \\
\hline Age 30-39 & 0.29 & 0.35 & 0.22 & 0.21 \\
\hline Age 40-49 & 0.33 & 0.23 & 0.18 & 0.22 \\
\hline Age 50-55 & 0.15 & 0.08 & 0.12 & 0.39 \\
\hline Age 55+ & 0.12 & 0.05 & 0.22 & 0.07 \\
\hline \multicolumn{5}{|l|}{ Education } \\
\hline Primary education & 0.12 & 0.16 & 0.19 & 0.22 \\
\hline Technical secondary education & 0.23 & 0.28 & 0.25 & 0.24 \\
\hline General secondary education & 0.33 & 0.30 & 0.27 & 0.25 \\
\hline Tertiary education & 0.32 & 0.26 & 0.13 & 0.20 \\
\hline Number of observations & $13,928,911$ & $2,173,943$ & $2,009,846$ & $18,112,700$ \\
\hline
\end{tabular}


Table A2: Monthly transition matrix - comparison of old law and new law

(in percent)

Panel A: Old law

\begin{tabular}{|c|c|c|c|c|c|c|c|c|c|}
\hline \multirow[t]{2}{*}{ Origin } & \multicolumn{8}{|c|}{ Destination } & \multirow[b]{2}{*}{ Total } \\
\hline & $\begin{array}{c}\text { Fixed-term } \\
\text { employment - same } \\
\text { employer }\end{array}$ & $\begin{array}{c}\text { Fixed-term } \\
\text { employment - new } \\
\text { employer }\end{array}$ & $\begin{array}{c}\text { Permanent } \\
\text { employment - same } \\
\text { employer }\end{array}$ & $\begin{array}{c}\text { Permanent } \\
\text { employment - new } \\
\text { employer }\end{array}$ & $\begin{array}{l}\text { Other employment } \\
\text { (e.g., self-emp.) }\end{array}$ & $\begin{array}{l}\text { Unemployment - } \\
\text { with unemp. } \\
\text { benefits }\end{array}$ & $\begin{array}{l}\text { Unemployment - } \\
\text { without unemp. } \\
\text { benefits }\end{array}$ & Inactivity & \\
\hline Fixed-term employment & 90.6 & 1.7 & 1.9 & 0.5 & 0.4 & 2.4 & 0.7 & 1.8 & 100.0 \\
\hline Permanent employment & 0.0 & 0.1 & 98.9 & 0.3 & 0.1 & 0.3 & 0.0 & 0.2 & 100.0 \\
\hline Other employment (e.g., self-employment) & 0.0 & 0.4 & 0.4 & 0.2 & 97.5 & 0.5 & 0.1 & 0.9 & 100.0 \\
\hline Unemployment (with unemp. benefits) & n.a. & 4.2 & n.a. & 1.0 & 1.2 & 84.8 & 0.2 & 8.6 & 100.0 \\
\hline Unemployment (without unemp. benefits) & n.a. & 2.5 & n.a. & 0.5 & 0.3 & n.a. & 93.5 & 3.0 & 99.9 \\
\hline
\end{tabular}

Unemployment (without

Panel B: New law

Origin

\section{Destination}

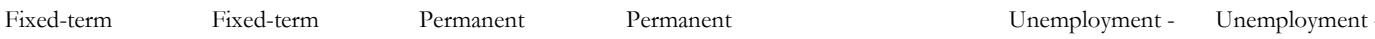

employment-same employment-new employment-same employment-new Other employment with unemp. without unemp.

\begin{tabular}{|c|c|c|c|c|c|c|c|c|c|}
\hline & employer & employer & employer & employer & (e.g., self-emp.) & benefits & benefits & Inactivity & Total \\
\hline Fixed-term employment & 90.4 & 1.5 & 2.4 & 0.6 & 0.3 & 1.9 & 1.0 & 2.0 & 100.0 \\
\hline Permanent employment & 0.0 & 0.1 & 98.9 & 0.3 & 0.1 & 0.2 & 0.1 & 0.3 & 100.0 \\
\hline Other employment (e.g., self-employment) & 0.0 & 0.3 & 0.6 & 0.3 & 96.8 & 0.4 & 0.2 & 1.4 & 100.0 \\
\hline Unemployment (with unemp. benefits) & n.a. & 4.5 & n.a. & 1.2 & 0.9 & 83.0 & 0.1 & 10.2 & 100.0 \\
\hline Unemployment (without unemp. benefits) & n.a. & 2.4 & n.a. & 0.5 & 0.4 & n.a. & 93.9 & 2.7 & 100.0 \\
\hline
\end{tabular}

Panel C: Difference = Panel B-Panel A Origin

Destination

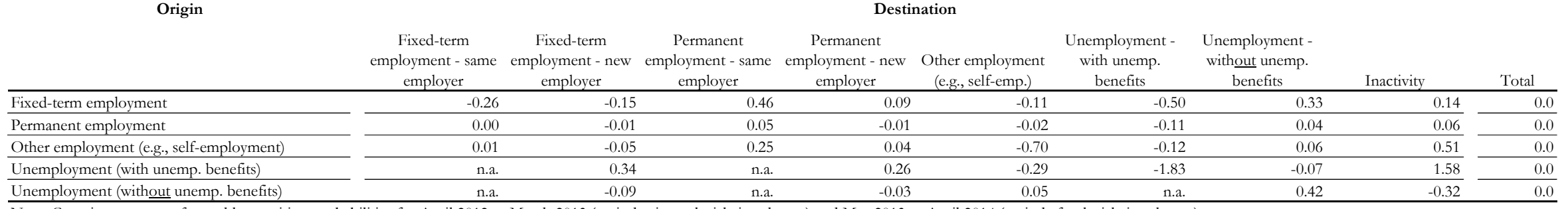

Note: Contains averages of monthly transition probabilities for April 2012 to March 2013 (period prior to legislative change) and May 2013 to April 2014 (period after legislative change).

Source: Own calculations based on combined unemployment and employment registry data, Statistical Office of the Republic of Slovenia. 
Table A3: Multinomial logit estimates of monthly probability of transition from fixed-term employment to different labour market states

Relative risk ratio of transition from fixed-term employment into:

\begin{tabular}{|c|c|c|c|c|c|c|c|}
\hline & $\begin{array}{c}\text { Permanent } \\
\text { employment - } \\
\text { same employer } \\
\text { (1) }\end{array}$ & $\begin{array}{c}\text { Inactivity } \\
\text { (2) }\end{array}$ & $\begin{array}{c}\text { Unemployment } \\
\text { without unemp. } \\
\text { benefits } \\
\text { (3) }\end{array}$ & $\begin{array}{c}\text { Fixed-term } \\
\text { employment - } \\
\text { new employer } \\
\text { (4) }\end{array}$ & $\begin{array}{c}\text { Permanent } \\
\text { employment - } \\
\text { new employer } \\
\text { (5) }\end{array}$ & $\begin{array}{l}\text { Unemployment - } \\
\text { with unemp. } \\
\text { benefits } \\
\text { (6) }\end{array}$ & $\begin{array}{c}\text { Self- } \\
\text { employment } \\
\text { (7) }\end{array}$ \\
\hline \multicolumn{8}{|c|}{ Effect of legislative changes (baseline: old law) } \\
\hline \multirow[t]{2}{*}{ New law } & $1.282^{* * *}$ & $1.039 * * *$ & $1.461 * * *$ & $0.901 * * *$ & $1.189 * * *$ & $0.809 * * *$ & $0.732 * * *$ \\
\hline & $(0.013)$ & $(0.011)$ & $(0.023)$ & $(0.01)$ & $(0.023)$ & $(0.008)$ & $(0.017)$ \\
\hline \multicolumn{8}{|l|}{ Gender (baseline: men) } \\
\hline \multirow[t]{2}{*}{ Women } & $0.945 * * *$ & $0.713 * * *$ & $1.527 * * *$ & $0.721 * * *$ & $0.810^{* * *}$ & $1.437 * * *$ & $1.790 * * *$ \\
\hline & $(0.008)$ & $(0.009)$ & $(0.026)$ & $(0.01)$ & $(0.017)$ & $(0.014)$ & $(0.045)$ \\
\hline \multicolumn{8}{|c|}{ Age (baseline: under 30 years old) } \\
\hline \multirow[t]{2}{*}{ Aged 30-39 } & $1.189 * * *$ & $0.746 * * *$ & $0.912^{* * *}$ & $1.049 * * *$ & $1.060 * * *$ & $1.143^{* * *}$ & $1.053^{*}$ \\
\hline & $(0.011)$ & $(0.01)$ & $(0.018)$ & $(0.015)$ & $(0.023)$ & $(0.014)$ & $(0.028)$ \\
\hline \multirow[t]{2}{*}{ Aged 40-49 } & $1.098^{* * *}$ & $0.705^{* * *}$ & $1.066^{* * * *}$ & $1.149 * * *$ & $1.080^{* * *}$ & $1.436^{* * * *}$ & $0.920^{* *}$ \\
\hline & $(0.013)$ & $(0.012)$ & $(0.024)$ & $(0.019)$ & $(0.028)$ & $(0.02)$ & $(0.033)$ \\
\hline \multirow[t]{2}{*}{ Aged 50-55 } & $0.910^{* * *}$ & $0.666^{* * *}$ & $1.458^{* * *}$ & 1.028 & $0.796 * * *$ & $1.977^{* * * *}$ & 0.978 \\
\hline & $(0.018)$ & $(0.017)$ & $(0.044)$ & $(0.027)$ & $(0.035)$ & $(0.037)$ & $(0.054)$ \\
\hline \multirow[t]{2}{*}{ Aged 55+ } & $0.937^{* *}$ & $0.666^{* * * *}$ & $1.185^{* * *}$ & $0.802 * * *$ & $0.539 * * *$ & $3.082 * * *$ & $0.813^{* * *}$ \\
\hline & $(0.024)$ & $(0.022)$ & $(0.05)$ & $(0.03)$ & $(0.037)$ & $(0.059)$ & $(0.059)$ \\
\hline \multicolumn{8}{|c|}{ Education (baseline: primary school or less) } \\
\hline \multirow[t]{2}{*}{ Secondary school (technical) } & $1.199 * * *$ & $0.673^{* * *}$ & $1.086^{* * *}$ & $0.954 * * *$ & $1.054^{*}$ & $1.029 *$ & $1.191 * * *$ \\
\hline & $(0.017)$ & $(0.01)$ & $(0.027)$ & $(0.016)$ & $(0.031)$ & $(0.015)$ & $(0.052)$ \\
\hline \multirow[t]{2}{*}{ Tertiary } & $1.492^{* * *}$ & $0.294^{* * *}$ & $0.671^{* * *}$ & $0.519 * * *$ & $1.082 * *$ & $0.774 * * *$ & $1.723^{* * *}$ \\
\hline & $(0.022)$ & $(0.006)$ & $(0.019)$ & $(0.011)$ & $(0.035)$ & $(0.013)$ & $(0.073)$ \\
\hline \multirow[t]{2}{*}{ Constant (baseline risk ratio) } & $0.012 * * *$ & $0.068^{* * *}$ & $0.004 * * *$ & $0.025^{* * * *}$ & $0.005 * * *$ & $0.016^{* * * *}$ & $0.001 * * *$ \\
\hline & $(0)$ & $(0.002)$ & $(0)$ & $(0.001)$ & $(0)$ & $(0)$ & $(0)$ \\
\hline Number of transitions & 48,397 & 39,338 & 17,578 & 34,462 & 11,802 & 47,479 & 7,674 \\
\hline Number of observations & \multicolumn{7}{|c|}{$2,173,943$} \\
\hline Pseudo R-squared & \multicolumn{7}{|c|}{0.027} \\
\hline \multicolumn{8}{|c|}{$\begin{array}{l}\text { Note: Coefficients denote relative risk ratios obtained from multinomial logit regressions, where relative risk ratios are defined as the relative probability of observing a given } \\
\text { outcome relative to the base outcome. Additional covariates included in the regressions include } 11 \text { dummy variables for calendar month and a dummy variable for April } 2013 \text {. } \\
\text { The regressions are estimated for monthly transitions from April } 2012 \text { to April } 2014 \text {, thus including } 12 \text { months before and after the legislative change (in addition to April } 2013 \text {, } \\
\text { when the new law went into effect in the middle of the month). *,** and *** denote statistical significance at the } 10 \%, 5 \% \text { and } 1 \% \text { levels, respectively. Standard errors clustered } \\
\text { by individual are in parentheses. }\end{array}$} \\
\hline
\end{tabular}


Table A4: Multinomial logit estimates of monthly probability of transition from fixed-term employment to different labour market states - age-specific effects of legislative changes

Relative risk ratio of transition from fixed-term employment into:

\begin{tabular}{|c|c|c|c|c|c|c|c|}
\hline & $\begin{array}{c}\text { Permanent } \\
\text { employment - } \\
\text { same employer } \\
\text { (1) }\end{array}$ & $\begin{array}{c}\text { Inactivity } \\
\text { (2) }\end{array}$ & $\begin{array}{l}\text { Unemployment - } \\
\text { without unemp. } \\
\text { benefits } \\
\text { (3) }\end{array}$ & $\begin{array}{c}\text { Fixed-term } \\
\text { employment - } \\
\text { new employer } \\
\text { (4) }\end{array}$ & $\begin{array}{l}\text { Permanent } \\
\text { employment - } \\
\text { new employer } \\
\text { (5) }\end{array}$ & $\begin{array}{l}\text { Unemployment - } \\
\text { with unemp. } \\
\text { benefits } \\
\text { (6) }\end{array}$ & $\begin{array}{l}\text { Self-employment } \\
\text { (7) }\end{array}$ \\
\hline \multicolumn{8}{|c|}{ Effects of new law, age-specific effects } \\
\hline \multirow[t]{2}{*}{ Aged 16-29 } & $1.202^{* * *}$ & 1.011 & $1.122^{* * *}$ & $0.887 * * *$ & $1.207 * * *$ & $0.926 * * *$ & $0.757 * * *$ \\
\hline & $(0.019)$ & $(0.015)$ & $(0.027)$ & $(0.016)$ & $(0.035)$ & $(0.015)$ & $(0.027)$ \\
\hline \multirow[t]{2}{*}{ Aged 30-39 } & $1.541 * * *$ & $1.122 * * *$ & $1.681 * * *$ & $0.930^{* * *}$ & $1.193^{* * *}$ & $0.808^{* * *}$ & $0.771^{* * *}$ \\
\hline & $(0.027)$ & $(0.022)$ & $(0.051)$ & $(0.019)$ & $(0.04)$ & $(0.015)$ & $(0.032)$ \\
\hline \multirow[t]{2}{*}{ Aged 40-49 } & $1.135^{* * *}$ & 1.015 & $1.781 * * *$ & $0.890 * * *$ & $1.224 * * *$ & $0.751 * * *$ & n.a. \\
\hline & $(0.026)$ & $(0.025)$ & $(0.065)$ & $(0.022)$ & $(0.053)$ & $(0.016)$ & \\
\hline \multirow[t]{2}{*}{ Aged 50-55 } & n.a. & n.a. & n.a. & n.a. & n.a. & $0.768^{* * *}$ & n.a. \\
\hline & & & & & & $(0.024)$ & \\
\hline \multirow[t]{2}{*}{ Aged 55+ } & n.a. & n.a. & n.a. & n.a. & n.a. & $0.543^{* * *}$ & n.a. \\
\hline & & & & & & $(0.019)$ & \\
\hline
\end{tabular}

Note: Coefficients denote relative risk ratios obtained from separate multinomial logistic regressions estimated by age group. Relative risk ratios are defined as the relative probability of observing a given outcome relative to the base outcome. For each age group, the following covariates are included: Gender, Educations (4 categories), dummy variables for calendar month and a dummy variable for April 2013. "n.a." refers to labour market states/transitions for which there were too few observations for reliable estimates. The regressions are estimated for monthly transitions from April 2012 to April 2014, thus including 12 months before and after the legislative change (in addition to April 2013 , when the new law went into effect in the middle of the month). *,** and ${ }^{* * *}$ denote statistical significance at the $10 \%, 5 \%$ and $1 \%$ levels, respectively. Standard errors clustered by individual are in parentheses.

Source: Own calculations based on combined unemployment and employment registry data, Statistical Office of the Republic of Slovenia. 
Table A5: Multinomial logit estimates of monthly probability of transition from permanent employment to different labour market states

Relative risk ratio of transition from permanent employment into:

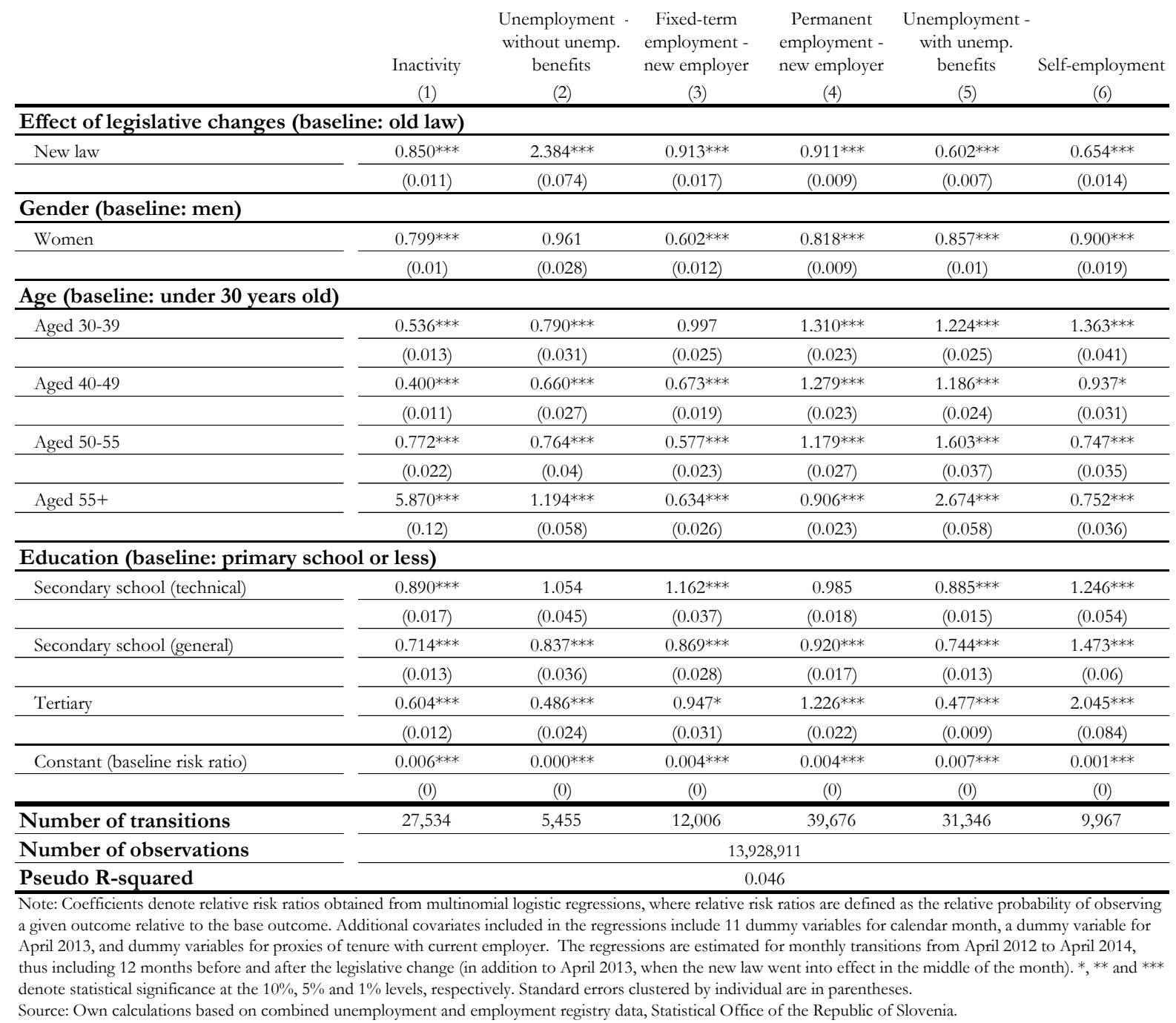


Table A6: Multinomial logit estimates of monthly probability of transition from permanent employment to different labour market states - agespecific effects of legislative changes

Relative risk ratio of transition from permanent employment into:

\begin{tabular}{|c|c|c|c|c|c|c|}
\hline & $\begin{array}{c}\text { Inactivity } \\
\text { (1) }\end{array}$ & $\begin{array}{l}\text { Unemployment - } \\
\text { without unemp. } \\
\text { benefits } \\
\text { (2) }\end{array}$ & $\begin{array}{c}\text { Fixed-term } \\
\text { employment - } \\
\text { new employer } \\
\text { (3) }\end{array}$ & $\begin{array}{c}\text { Permanent } \\
\text { employment - } \\
\text { new employer } \\
\text { (4) }\end{array}$ & $\begin{array}{l}\text { Unemployment - } \\
\text { with unemp. } \\
\text { benefits } \\
\text { (5) }\end{array}$ & $\begin{array}{c}\text { Self-employment } \\
\text { (5) }\end{array}$ \\
\hline \multirow[t]{2}{*}{ Aged 16-29 } & $1.177 * * *$ & n.a. & 1.059 & $1.140^{* * *}$ & $0.718^{* * *}$ & $0.695^{* * *}$ \\
\hline & $(0.042)$ & & $(0.041)$ & $(0.032)$ & $(0.024)$ & $(0.035)$ \\
\hline \multirow[t]{2}{*}{ Aged 40-49 } & $1.126^{* * *}$ & $3.725^{* * *}$ & $0.903^{* * *}$ & $0.869 * * *$ & $0.720^{* * *}$ & $0.619^{* * *}$ \\
\hline & $(0.042)$ & $(0.25)$ & $(0.034)$ & $(0.015)$ & $(0.016)$ & $(0.025)$ \\
\hline \multirow[t]{2}{*}{ Aged 50-55 } & $0.912 * *$ & $3.658^{* * *}$ & $0.890^{*}$ & $0.839 * * *$ & $0.599 * * *$ & $0.616 * * *$ \\
\hline & $(0.04)$ & $(0.38)$ & $(0.06)$ & $(0.025)$ & $(0.019)$ & $(0.048)$ \\
\hline
\end{tabular}

Note: Coefficients denote relative risk ratios of multinomial logit regressions estimated for each age group separately, where relative risk ratios are defined as the relative probability of observing a given outcome relative to the base outcome. For each age group, the following covariates are included: Gender, Educations (4 categories),

dummy variables for calendar month, a dummy variable for April 2013 and dummy variables for proxies of tenure with current employer. "n.a." refers to labour market states/transitions for which there were too few observations for reliable estimates. The regressions are estimated for monthly transitions from April 2012 to April 2014 , thus including 12 months before and after the legislative change (in addition to April 2013 , when the new law went into effect in the middle of the month). *,** and *** denote statistical significance at the $10 \%, 5 \%$ and $1 \%$ levels, respectively. Standard errors clustered by individual are in parentheses.

Source: Own calculations based on combined unemployment and employment registry data, Statistical Office of the Republic of Slovenia. 
Table A7: Multinomial logit estimates of monthly probability of transition from unemployment to different labour market states

Relative risk ratio of transition from unemployment into:

Fixed-term Permanent

employment-new employment - new

employer

employer

Self-employment

(1)

(2)

(3)

\begin{tabular}{|c|c|c|c|}
\hline \multicolumn{4}{|c|}{ Effect of legislative changes (baseline: old law) } \\
\hline \multirow[t]{2}{*}{ New law } & $1.027 * * *$ & $1.121 * * *$ & $0.852^{* * *}$ \\
\hline & $(0.009)$ & $(0.019)$ & $(0.016)$ \\
\hline \multicolumn{4}{|l|}{ Gender (baseline: men) } \\
\hline \multirow[t]{2}{*}{ Women } & $0.688^{* * *}$ & $0.617^{* * *}$ & 0.99 \\
\hline & $(0.008)$ & $(0.012)$ & $(0.02)$ \\
\hline \multicolumn{4}{|c|}{ Age (baseline: under 30 years old) } \\
\hline \multirow[t]{2}{*}{ Aged 30-39 } & $0.843^{* * *}$ & $0.899 * * *$ & $1.474 * * *$ \\
\hline & $(0.012)$ & $(0.02)$ & $(0.037)$ \\
\hline \multirow[t]{2}{*}{ Aged 40-49 } & $0.862^{* * *}$ & $0.819 * * *$ & $1.591 * * *$ \\
\hline & $(0.014)$ & $(0.021)$ & $(0.045)$ \\
\hline \multirow[t]{2}{*}{ Aged 50-55 } & $0.751 * * *$ & $0.529 * * *$ & $1.797 * * *$ \\
\hline & $(0.017)$ & $(0.02)$ & $(0.065)$ \\
\hline \multirow[t]{2}{*}{ Aged $55+$} & $0.474 * * *$ & $0.188^{* * *}$ & $1.274 * * *$ \\
\hline & $(0.013)$ & $(0.011)$ & $(0.051)$ \\
\hline \multicolumn{4}{|c|}{ Education (baseline: primary school or less) } \\
\hline \multirow[t]{2}{*}{ Secondary school (technical) } & $1.864^{* * *}$ & $2.129 * * *$ & $2.123^{* * *}$ \\
\hline & $(0.032)$ & $(0.066)$ & $(0.076)$ \\
\hline \multirow[t]{2}{*}{ Secondary school (general) } & $1.757^{* * *}$ & $2.593^{* * *}$ & $3.202^{* * *}$ \\
\hline & $(0.03)$ & $(0.078)$ & $(0.108)$ \\
\hline \multirow[t]{2}{*}{ Tertiary } & $2.420^{* * *}$ & $4.226^{* * *}$ & $5.794 * * *$ \\
\hline & $(0.046)$ & $(0.137)$ & $(0.208)$ \\
\hline \multirow[t]{2}{*}{ Constant (baseline risk ratio) } & $0.078^{* * *}$ & $0.021 * * *$ & $0.006^{* * *}$ \\
\hline & $(0.002)$ & $(0.001)$ & $(0)$ \\
\hline Number of transitions & 68,302 & 15,521 & 13,225 \\
\hline Number of observations & \multicolumn{3}{|c|}{$2,009,846$} \\
\hline \multicolumn{2}{|c|}{ Pseudo R-squared } & 0.172 & \\
\hline \multicolumn{4}{|c|}{$\begin{array}{l}\text { Note: Coefficients denote relative risk ratios obtained from multinomial logistic regressions, where relative risk ratios are } \\
\text { defined as the relative probability of observing a given outcome relative to the base outcome. Additional covariates included in } \\
\text { the regressions include a dummy variable for receipt of unemployment benefits, } 11 \text { dummy variables for calendar month and a } \\
\text { dummy variable for April } 2013 \text {. The regressions are estimated for monthly transitions from April } 2012 \text { to April } 2014 \text {, thus } \\
\text { including } 12 \text { months before and after the legislative change (in addition to April } 2013 \text {, when the new law went into effect in the } \\
\text { middle of the month). } * * * \text { and } * * * \text { denote statistical significance at the } 10 \%, 5 \% \text { and } 1 \% \text { levels, respectively. Standard errors } \\
\text { clustered by individual are in parentheses. } \\
\text { Source: Own calculations based on combined unemployment and employment registry data, Statistical Office of the Republic of } \\
\text { Slovenia. }\end{array}$} \\
\hline
\end{tabular}


Table A8: Multinomial logit estimates of monthly probability of transition from unemployment to different labour market states - age-specific effects of legislative changes

Relative risk ratio of transition from unemployment into:

Fixed-term employment - Permanent employment -

new employer new employer Self-employment

(1) (2) (3)

\begin{tabular}{|c|c|c|c|}
\hline \multicolumn{4}{|c|}{ Effects of new law, age-specific effects } \\
\hline \multirow[t]{2}{*}{ Aged 16-29 } & $1.153^{* * *}$ & $1.294 * * *$ & $1.407 * * *$ \\
\hline & $(0.016)$ & $(0.034)$ & $(0.049)$ \\
\hline \multirow[t]{2}{*}{ Aged 30-39 } & 1.006 & 1.05 & 0.952 \\
\hline & $(0.016)$ & $(0.032)$ & $(0.031)$ \\
\hline \multirow[t]{2}{*}{ Aged 40-49 } & $1.033^{*}$ & 1.062 & $0.717^{* * *}$ \\
\hline & $(0.019)$ & $(0.04)$ & $(0.028)$ \\
\hline \multirow[t]{2}{*}{ Aged 50-55 } & $0.900 * * *$ & 0.912 & $0.455^{* * *}$ \\
\hline & $(0.025)$ & $(0.061)$ & $(0.026)$ \\
\hline \multirow[t]{2}{*}{ Aged 55+ } & $0.717 * * *$ & 1.161 & $0.331 * * *$ \\
\hline & $(0.026)$ & $(0.128)$ & $(0.025)$ \\
\hline \multicolumn{4}{|c|}{$\begin{array}{l}\text { Note: Coefficients denote relative risk ratios obtained from separate multinomial logistic regressions estimated by age group. Relative risk } \\
\text { ratios are defined as the relative probability of observing a given outcome relative to the base outcome. For each age group, the following } \\
\text { covariates are included: Gender, Educations ( } 4 \text { categories), dummy variables for calendar month and a dummy variable for April } 2013 . \\
\text { "n.a." refers to labour market states/transitions for which there were too few observations for reliable estimates. The regressions are } \\
\text { estimated for monthly transitions from April } 2012 \text { to April } 2014 \text {, thus including } 12 \text { months before and after the legislative change (in } \\
\text { addition to April } 2013 \text {, when the new law went into effect in the middle of the month). *, ** and *** denote statistical significance at the } \\
10 \%, 5 \% \text { and } 1 \% \text { levels, respectively. Standard errors clustered by individual are in parentheses. } \\
\text { Source: Own calculations based on combined unemployment and employment registry data, Statistical Office of the Republic of Slovenia. }\end{array}$} \\
\hline
\end{tabular}

